
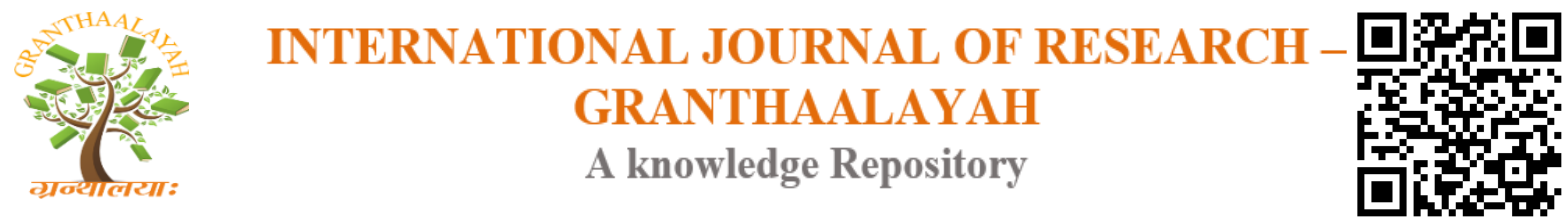

Social

\title{
A CASE STUDY OF THE EFL LEARNER'S NEEDS ANALYSIS BASED ON KRASHEN'S MONITOR THEORY
}

\author{
Yunjie Huang ${ }^{1}$, Yi Zhang ${ }^{2}$ \\ ${ }^{1,2}$ School of Foreign Studies, Northwestern Polytechnical University, China
}

\begin{abstract}
Learners play a vital role in the process of second language acquisition (SLA). Needs analysis can realistically reflect learners' circumstances when learning the second language. In the presented paper, one EFL learner was selected as a case to do the needs analysis, in which the interview was the main instrument for the analysis. Based on Krashen's monitor theory, results found that, firstly, the learner's English needs had not been met. Then, insufficient input as well as complex and an extremely high affective filter were two significant reasons for the failure of needs accomplishment. Additionally, this case study provided the suggestions responding to the specific circumstances of a high affective filter and offered the experience for the further larger-scaled studies of related needs analysis.
\end{abstract}

Keywords: Second Language Acquisition; Krashen; Needs Analysis.

Cite This Article: Yunjie Huang, and Yi Zhang. (2019). "A CASE STUDY OF THE EFL LEARNER'S NEEDS ANALYSIS BASED ON KRASHEN'S MONITOR THEORY." International Journal of Research - Granthaalayah, 7(8), 265-272. https://doi.org/10.29121/granthaalayah.v7.i8.2019.669.

\section{Introduction}

When looking through the second language acquisition from a learner's perspective, learner's needs analysis (NA) can be a realistic direction, in which learners play a core role. As a case study, this paper firstly presents the results of the needs analysis of an EFL learner, followed by a corresponding discussion based on Krashen's monitor theory. The purpose of this case study is to explain the pilot analysis of L2 learner's needs analysis from Krashen's hypothesis and then to provide experience for the larger-scaled analysis of learners' needs.

\subsection{Needs Analysis}

Needs analysis referred to the technology and method of studying needs employing introspection, interview, observation and questionnaire (Shu, 2004; Chen \& Wang, 2009). In the field of SLA, especially foreign language teaching, NA was as important as the diagnosis before a doctor prescribes a prescription (Chaudron, 2005). Theoretically, different researchers defined and 
classified needs from the distinctive viewpoint, objects and backgrounds (Munby, 1978; Allwright, 1982; Hutchinson \& Water, 1987; Dudley-Evans \& St John, 1998). Practically and pedagogically, NA had a wide range of applications in the English for specific purpose (ESP) field. Related studies covered syllabus design, course compilation, textbook design, teaching evaluation, and so forth (Cai, 2012a; Cai, 2012b; Huang, 2013; Peng, 2018). In this case study, NA was employed to obtain the general information of L2 learner's learning experience as well as expectation. For the reason that the interviewee in this study was an EFL learner at college, Chen's (2010) college English needs analysis model was used (see detailed information in the Appendix A), which was constructed on the basis of the models of the existing literature and focused on students' individual needs and social needs.

\subsection{Krashen's Monitor Theory}

Krashen (1982) established the monitor theory, of which five hypotheses were put forward, including the acquisition-learning hypothesis, the natural order hypothesis, the monitor hypothesis, the input hypothesis and the affective filter hypothesis. Studies related to Krashen's theory covered diverse topics, including the application of hypotheses in teaching Chinese as a foreign language (Yang, 2004; Bai, 2009; Zhu, 2012), theoretical investigation (Wang, 2012) and discussion of the hypotheses (Yang \& Li, 2003; Zafar, 2011; Liu, 2015). In this analysis, Krashen's hypotheses were considered when analysing the results of needs analysis, aiming at providing possible reasons for achievement or failure of meeting leaner's needs.

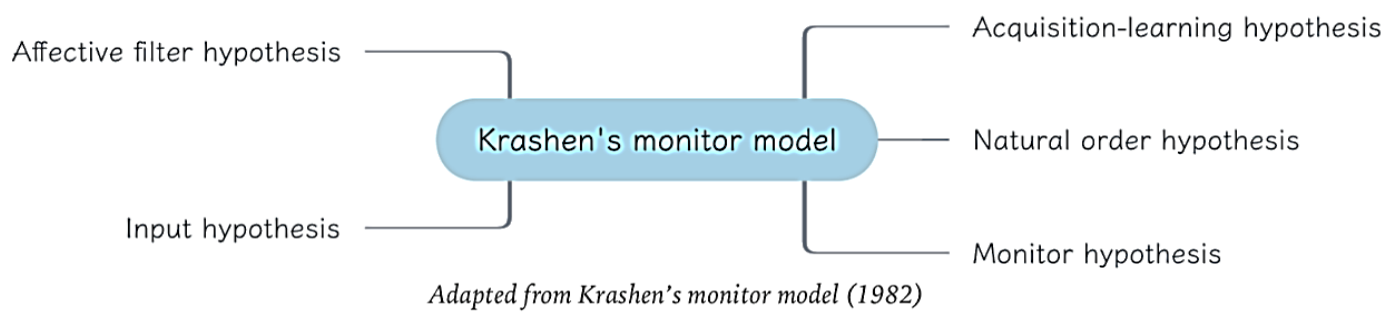

Figure 1.1: Krashen's monitor model (Adapted from Krashen, 1982)

The following sections firstly introduce the design and procedure of this study. Then the fundamental questions for the inquiry of participant's general information and follow-up questions are introduced with a brief explanation. After that, findings of the needs analysis are presented, followed by a discussion based on Krashen's theory. As a final point, the reflective thinking of the author is shared.

\section{Materials and Methods}

\subsection{Basic Inquiry and Interview}

The basic questions and further interview with follow-up questions were used for this study. Based on the college English needs analysis model (Chen, 2010), the questions of essential inquiry were used to understand the general information of the interviewee, for instance, the basic Englishlearning background, and to make sure that whether his learning experience met his needs. For the sake of making this analysis as concrete and thorough as possible, the focus was only put on the English learning experience of the interviewee when he took the Academic Oral English course at NPU. Similar to Chen's model, fundamental questions were designed and arranged in four 
dimensions: learning ability gap, individual desires of the learner, needs for learning process and needs for learning environment.

The interview was carried out online after answering the basic questions and preliminary analysis. This interview lasted for about one hour. Based on the results of needs analysis, questions (see the detailed description in Appendix B) for interview were designed taking Krashen's input hypothesis, monitor hypothesis and affective filter hypothesis into consideration. Questions could be divided into main questions and additional questions. Leading questions were the further investigation of results of the needs analysis while additional ones were attached to make the main questions clearer and more comprehensive.

\subsection{Description of the Participant}

The interviewee is a male master student majoring in mechatronics engineering at Zhejiang University, and he graduated from NPU in 2018. When he was a freshman, he took Academic Oral English course for one semester. Except for class time, every day he spent 1-2hour(s) learning English. Till the beginning of the course, he had been learning English for 14 years. As a student who passed the college entrance examination in Jiangsu province and entered the university, his English is above average.

\section{Findings and Discussions}

Through reflecting results of questions with the purpose to understand the overall results of needs analysis, it was clear that the learner's needs were met unsuccessfully. Probing into the reasons of failure, input hypothesis and affective filter hypothesis should be concentrated.

\subsection{Learner's Needs Were Not Met}

Although the student had a strong desire to improve the knowledge of academic English and oral English in this course, his needs did not meet successfully.

Interviewee: "I thought the content of this course was broad and very general. However, because it was too general, it had little effect when I wanted to apply it to my major - mechatronic engineering. To the most extent, it only had the effect broadening my horizon. Additionally, my basic skill such as spoken English didn't be improved either, because chances for practising were very limited."

As respects the learner's explanation, it is possible that reasons for unsuccessful achievement of needs can be mainly divided into two facets. From one aspect, the design of this course encompassing the content and teaching methods is not so appropriate. From another aspect, there appears a negative effect when learner's expectation is dashed.

\subsection{Comprehensible but Insufficient Input}

Krashen's input hypothesis emphasises two significant conditions, of which one is that the input should be comprehensible, and another one is that the input should be sufficient. 
Interviewee: "In class, the teacher always gave a systematic explanation first, and let students practice in groups on selected topics. After that, we were required to present our practice. Finally, the teacher commented. I thought that she instructed logically, and I could understand most of the content efficiently."

Due to the learner's positive comment on the teacher's instruction of knowledge, relatively the input is comprehensible. However, regarding the process of grasping and practising the new knowledge as the process of providing input, limited chances for learners to practice lead to the limited degree of grasping and digesting the input. Thus, the input is more or less insufficient.

\subsection{Complex and Extremely High Affective Filter}

As for this interviewee, affective factors treated as reasons for the failure of meeting needs were complex. The basic inquiry indicated that he had a strong desire to improve his English performance, for instance, oral English. Furthermore, he had the motivation to learn English to make him communicate with foreigners easily and to get a good job after graduation. Nevertheless, an affective matter still became a formidable obstacle in his English learning.

Interviewee: "I would not look forward to this course every week, because I hated English class at that time. There was a lot of interaction in English class, and I didn't like interaction at all. I was usually very nervous and worried when I take this course."

The learner's resistance blocks his passion in attending the oral English course, for which the main reason is his overwhelming fear of interaction between teachers and students. This negative feeling makes the process of receiving the input passive and more difficult.

Interviewee: "I did not expect group practice and presentation at all. I aimed to be an unknown person in the class. However, if I had relevant experience of the given topic, I would like to speak more. It would be easier for me to make sentences and express myself."

Apart from the negative feeling when he attends the class, he is afraid of expressing himself either. He stated that sometimes he was willing to say something, but inevitably, many topics could not match his experience. His unavoidable terror hinders the practice of oral English and, moreover, the input of the knowledge. When making specific enquiries about the reasons for this kind of fear, he said candidly that he was "afraid of losing face."

By and large, the interviewee had the motivation in English learning. Nonetheless, his severe negative emotion or phycological barrier makes the filter up and prevents the input from passing through, which is probably the most significant reason for the failure of meeting his needs.

\subsection{Reflective Thinking and Discussion}

To some extent, the affective filter can determinate the grasp of input. It seems that this kind of high filter is not an exceptional case. Because of personal factors such as being shy or afraid of expressing ourselves and losing face in front of others, learners always cannot receive the input efficiently and slickly. When asked the interviewee that why did he choose the oral English course 
if he did not like the interaction, his answer was impressive - "being motivated doesn't mean I like it". It shows that sometimes learners might make a reluctant choice because of some individual or social factors that can be regarded as the component of motivation. For instance, to pass CET 4 or 6 examinations (the important examination used to evaluate English talent of college students in Chinese universities), to gain a perfect job, or even to obtain others' respect. But this choice is made with a negative emotion, which brings about the passive learning process and unenthusiastic learning attitude.

What if learners have a lower filter? It is more possible for learners to meet their needs and receive input successfully. Usually, teachers can do a few things with this kind of complex filter - "I know it's important to express myself, but I'm afraid of losing face." No matter how teachers encourage students, those who have a fear of losing face still say nothing. To a great extent, one probably can merely lower or eliminate this affective filter by himself. On the one hand, learners might be more confident and can express himself to others through keeping self-encouragement and selfsuggestion. On the other hand, teachers' effort should not be ignored. It is of great necessity for teachers to carry out some necessary but reasonable measures like making the rules pushing students to practice expressing themselves. Particularly, for those students who have a complex and high affective filter, forcing them to speak more and express more might have a certain effect.

\section{Conclusions and Recommendations}

It has been well recognized that both teachers and learners play a vital role in second language acquisition. From the interview of this case study, the teacher's responsibility is relatively accomplished, providing comprehensible input and monitoring students appropriately. Furthermore, teachers tried her best to lower the affective filter of the learner. However, learner's needs were still not met because of his complex and a rather high filter. In order to lower the affective filter of the learner, self-encouragement and self-suggestion are two practical ways. Additionally, teachers should take measures like making rules or giving encouragement to those learners to hold high affective filter as well.

The study shows that there still exists the room for improvement in this kind of needs analysis. First of all, the option set for the questions in the essential inquiry should be more explicit. For example, for those questions in relation to the frequency of some English study, numerical values (like 1-6) can be used for more explicit calculation. Secondly, this case study merely considered the input hypothesis of Krashen's model. However, output hypothesis is necessary as well.

\section{Acknowledgements}

The authors would like to express their gratefulness for Associate Prof. Liu Fei's constructive suggestions. This research paper is sponsored by the Seed Foundation of Innovation and Creation for Graduate Students in Northwestern Polytechnical University (ZZ2019046). 


\section{Appendices}

APPENDIX A: The sample of college English needs analysis model adapted from Chen (2009)

Table 1: The first dimension: Learning ability gap

\begin{tabular}{|c|c|c|}
\hline Content & Details & Additional information \\
\hline \multirow{3}{*}{$\begin{array}{l}\text { Basic information } \\
\text { about English learning } \\
\text { at present }\end{array}$} & Age/sex/major & \\
\hline & Educational background & \\
\hline & $\begin{array}{l}\text { The average amount of time } \\
\text { spent learning English every } \\
\text { day }\end{array}$ & Except for the class time \\
\hline \multirow{3}{*}{$\begin{array}{l}\text { Self-evaluation of } \\
\text { current English skills }\end{array}$} & Basic skills & Listening/speaking/reading/translating \\
\hline & General skills & Grammar/phonetic knowledge/lexis \\
\hline & Cultural background & \\
\hline \multirow{3}{*}{$\begin{array}{l}\text { Difficulties in learning } \\
\text { English at present }\end{array}$} & Basic skills & Listening/speaking/reading/translating \\
\hline & General skills & Grammar/phonetic knowledge/lexis \\
\hline & Cultural background & \\
\hline
\end{tabular}

Table 2: The second dimension: Individual desires of the learner

\begin{tabular}{|l|l|l|}
\hline Content & Details & Additional information \\
\hline \multirow{4}{*}{$\begin{array}{l}\text { Desires for improving } \\
\text { distinctive English skills }\end{array}$} & Basic skills & Listening/speaking/reading/translating \\
\cline { 2 - 3 } Eurpose/Motivation for & General skills & Grammar/phonetic knowledge/lexis \\
\cline { 2 - 3 } & Interested in English & \\
\cline { 2 - 3 } & For Communication & \\
\cline { 2 - 3 } & $\begin{array}{l}\text { To understand a } \\
\text { foreign culture }\end{array}$ & \\
\cline { 2 - 3 } & For further study & $\begin{array}{l}\text { To take examinations for a graduate } \\
\text { programme/ To study abroad }\end{array}$ \\
\cline { 2 - 3 } & To pass CET-4/6 exam & \\
\cline { 2 - 3 } & To get credit & \\
\cline { 2 - 3 } & To have a good job & After graduation \\
\hline
\end{tabular}

APPENDIX B: Detailed description of questions for further interview

Table 3: Questions for further interview

\begin{tabular}{|c|c|c|}
\hline Main questions & Additional questions & Purpose \\
\hline $\begin{array}{l}\text { Whether your expected teaching } \\
\text { effect was realized? }\end{array}$ & $\begin{array}{l}\text { Whether your basic skills were } \\
\text { improved? }\end{array}$ & $\begin{array}{l}\text { To understand the } \\
\text { general result of } \\
\text { needs analysis }\end{array}$ \\
\hline $\begin{array}{l}\text { What was the exact form of a } \\
\text { teaching method? }\end{array}$ & $\begin{array}{l}\text { Did you have pair work (pattern } \\
\text { drill)? }\end{array}$ & \multirow[t]{2}{*}{$\begin{array}{l}\text { To examine the } \\
\text { input hypothesis }\end{array}$} \\
\hline $\begin{array}{l}\text { Did the teacher instruct students } \\
\text { systematically? }\end{array}$ & $\begin{array}{l}\text { Could you grasp and digest the } \\
\text { teacher's instruction? }\end{array}$ & \\
\hline $\begin{array}{l}\text { How did the teacher deal with the } \\
\text { difficult terms? }\end{array}$ & $\begin{array}{l}\text { Did the teacher use English or } \\
\text { Chinese? }\end{array}$ & $\begin{array}{l}\text { To examine the } \\
\text { monitor hypothesis }\end{array}$ \\
\hline
\end{tabular}




\begin{tabular}{|c|c|c|}
\hline $\begin{array}{l}\text { When you did self-performance } \\
\text { (communication), did the teacher } \\
\text { correct your utterance? }\end{array}$ & & \\
\hline $\begin{array}{l}\text { Did you expect to take this course } \\
\text { every week? }\end{array}$ & $\begin{array}{l}\text { What was your emotion when } \\
\text { taking this course? }\end{array}$ & \multirow{5}{*}{$\begin{array}{l}\text { To examine the } \\
\text { affective filter } \\
\text { hypothesis }\end{array}$} \\
\hline $\begin{array}{l}\text { Did you look forward to } \\
\text { participating in group work? }\end{array}$ & & \\
\hline \multirow[t]{2}{*}{$\begin{array}{l}\text { What was your emotion when } \\
\text { participating in group work? }\end{array}$} & $\begin{array}{l}\text { Why did you have such } \\
\text { emotion? }\end{array}$ & \\
\hline & $\begin{array}{l}\text { Did the teacher spare efforts to } \\
\text { lesson your pressure? }\end{array}$ & \\
\hline $\begin{array}{l}\text { Why did you have no motivation of } \\
\text { attending the class but had the } \\
\text { desire for improving basic skills? }\end{array}$ & $\begin{array}{l}\text { Why did you choose the oral } \\
\text { English course if you did not } \\
\text { like interaction between } \\
\text { teachers and students? }\end{array}$ & \\
\hline
\end{tabular}

\section{References}

[1] Allwright, R. Perceiving and Pursuing Learner's Needs. In M. Geddes, \& G. Stutridge, Individualisation. Oxford: Modern English Publications.1982.

[2] Bai, Y. Krashen's theory of "input hypothesis" and "affective filter hypothesis" and college public foreign language listening and speaking teaching. Journal of capital university of economics and business, 2009, 11(06), 122-125.

[3] Bingbing, C. Theoretical construction of demand analysis model for college English. Journal of foreign languages (02), 2010, 120-123.

[4] Cai, J.. Research on curriculum model of university ESP based on demand analysis. Foreign language teaching 33(03), 2012, 47-50.

[5] Cai, J. Demand analysis and teaching method research of "English for academic purposes". Theory and practice of foreign language teaching (02), 2012, 30-35+96.

Chaudron, C. A Task-based Needs Analysis of a Teritiary Korean as a Foreign Language Program. In M. Long, Second Language Needs Analysis. Cambridge: CUP, 2005.

[6] Chen, B., \& Wang, H. A review of foreign language demand analysis in China. Foreign language and foreign language teaching (07), 18-21+28, 2009.

[7] Chen, F. Research on tourism English courses based on demand analysis. Nanchang: jiangxi normal university, 2013.

[8] Chen, B. Theoretical construction of demand analysis model for college English. Journal of foreign languages (02), 2010, 120-123.

[9] Dudley-Evans, T., \& St John, M. Developments in English for Specific Purposes: A Multidisciplinary approach. Cambridge: CUP, 1998.

[10] Huang, Y. Demand analysis-based survey on esp teaching - a case study of medical English. Nanjing: nanjing normal university, 2013.

[11] Hutchinson, T., \& Water, A. English for Specific Purposes - A Learning-centered Approach. Cambridge: CUP, 1987.

[12] Krashen, S. Principles and Practice in Second Language Acquisition. New York: Pergamon Press, 1982.

[13] Liu, D. A Critical Review of Krashen's Input Hypothesis: Three Major Arguments. Journal of Education and Human Development, 4(4), Des, 2015, 139-146.

[14] Munby, J. Communicative Syllabus Design. Cambridge: CUP, 1978. 
[15] Peng, P. The development of foreign language demand analysis at home and abroad. Journal of jiangxi normal university (philosophy and social science edition)) (51(05)), 140-144, 2018.

[16] Shu, D. Foreign language teaching reform: problems and countermeasures. Shanghai: Shanghai foreign language publishing house, 2004.

[17] Wang, C. The construction of college English acquisition model -- from the perspective of krashen's theory (10), 271-272, 2012.

[18] Yang, R. The role of input method and affective filtering method in college English teaching. Journal of south central university for nationalities (humanities and social sciences edition) (S2), 247-249, 2004.

[19] Yang, W., \& Li, T. Discussion on monitoring model of second language acquisition. Educational exploration (06), 76-77, 2003.

[20] Zafar, M. Monitoring the 'Monitor': A Critique of Krashen's Five Hypothesis. Dhaka University Journal of Linguistics (2(4)), 139-146, 2011.

[21] Zhu, W. Application of "input hypothesis" theory in teaching Chinese as a foreign language. Hubei social science (06), 139-142, 2012.

\footnotetext{
*Corresponding author.

E-mail address: yizhang@ nwpu.edu.cn
} 